\title{
Bibliometric Analysis on the Resource Rooms for Learning in Regular Class in Our Country in the Recent Twenty Years
}

\author{
Xiu Li \\ College of Special Education \\ Leshan Normal University \\ Leshan, China 614000
}

\begin{abstract}
Bibliometric analysis is applied to review the research results of resource room for learning in regular class of our country from 1999 to 2016 . The results reveal: although the amount of research literature on resource room for learning in regular class increases yearly, the research is still at initial stage; the researchers of resource room for learning in regular class are staff of colleges or research centers from Eastern China. The core research groups haven't formed so far. The self-complied or adapted questionnaires are used to investigate the construction and operation of resource room for learning in regular class. The construction level of resource room fails to meet the requirements on the guide. The research hotspot centers on practice of resource room and is unsystematic. Heavy responsibilities should be shouldered to research the resource rooms for learning in regular class.
\end{abstract}

Keywords-learn in regular class; resource room; research status and reflection

\section{INTRODUCTION}

The ideological trend of inclusive education prevailed in the 1990s. In the 1980s, researchers proposed the learning in regular class with Chinese characteristics according to the fundamental realities of the country. Regular children and special children learn in the same school and the same classroom. Schools can provide class for special children [1]. The pattern is rapidly popularized in China. By 2014, there are 209,124 special children receiving education in regular schools, accounting for $53 \%$ of the total number of the disabled [2]. However, many special children fail to enter regular schools. Some special children return to special schools because they have problem with learning in regular schools. The development of learning in regular class is caught in a bottleneck [3]. It is of vital importance to construct resource rooms to solve problems and promote the development of learning in regular class. It proposes in the Promotion Plan for Special Education (2014-2016) issued by the Ministry of Education in January 2014 that we must continue to support the development of special education, let regular schools construct resource rooms (centers) equipped with tools to provide individualized service for special children. Definite provisions on functions, basic layouts, place and environment, zone setting, resource teachers and management standards of resource rooms have been specified in the Construction Guidelines on Resource Room for Special Education in Regular Schools issued by the Ministry of Education in 2016. In recent years, researchers have researched the resource rooms for learning in regular class. The existing research achievements will be analyzed to explore the development direction of research on construction of resource rooms and provide references for functional departments.

\section{RESEARCH OBJECTS AND METHODS}

\section{A. Literature Sampling}

In this paper, CNKI full text database serves as the search platform. Precise search has been conducted with "resource room for learning in regular class" as the keyword. Thirty-four literatures and theses are included. The time range is eighteen years from 1999 to 2016.

\section{B. Analytical Unit}

Literatures collected can be divided into three analytical units. This first part includes the number of literatures, analysis on the unit and region of the first signed unit of the works. The second part includes the research results and main contents of resource rooms for learning in regular class. The third part includes hotspots and development of research on resource rooms for learning in regular class.

\section{Statistical Approach}

Use frequency and percentage to carry out statistics.

\section{StATISTICAL RESULTS AND ANALYSIS}

\section{A. General Analysis on the Number of Literatures}

There are thirty-four literatures with the theme of "resource room for learning in regular class" collected in CNKI Chinese Journal of Full-text Database from 1999 to 2016 (according to the retrieved results on June 1, 2016). In the same corresponding time frame, there are 799 (Table 1) literatures with research topic of "learning in regular class". It includes the research on the resource rooms for learning in regular class and the research on learning in regular class. From 1999 to 
2001, the numbers of literature related to the former and the latter are one and sixty-four respectively; from 2002 to 2004, the numbers of literature related to the former and the latter are three and sixty-four respectively; from 2005 to 2007, the numbers of literature related to the former and the latter are five and ninety-eight respectively; from 2008 to 2010, the numbers of literature related to the former and the latter are three and one hundred and thirty-seven respectively; from 2011 to 2013 , the numbers of literature related to the former and the latter are nine and one hundred and ninety-seven respectively; from 2014 to 2016, the numbers of literature related to the former and the latter are thirteen and two hundred and twentythree respectively. Obviously, on the whole, the number of research literature on resource room for learning in regular class increases yearly from 1999 to 2016, only decreases from 2008 to 2010 and increases greatly in the recent three years; the percentage that the number of literature researching the resource class for learning in regular class account for in the total number of this kind has synchronized growth. However, the literature related to the research on resource rooms for learning in regular class accounts for a small proportion. Compared with researches on learning in regular class, the researches on resource rooms for the learning in regular class are weak at the same period.

\section{B. Analysis on the Region and the Property of Work Unit of the First Author}

The regional distribution of author researching resource rooms for learning in regular class is reflected according to the number of statistical literatures of the first author in different provinces (one time for each literature). The regions to which the first authors of thirty-four literatures belong are nine provinces and cities: eight in Shanghai, seven in Beijing, five in Jiangsu, five in Chongqing, four in Zhejiang, one in Gansu, one in Anhui, one in Hubei and one in Sichuan. The region to which the first author belongs is unclear in one literature. It shows the authors researching resource rooms for learning in regular class of our country distribute in Eastern China, North China and the southwest with numbers of eighteen, seven and six respectively, corresponding to the development situation of inclusive education of our country. The first authors of twentyfive research literatures distribute in Beijing, Jiangsu, Shanghai and Chongqing, accounting for $73.5 \%$ of the total number of literatures. The researches on resource rooms for learning in regular class of our country mainly distribute in Eastern China, North China and the southwest, accounting for $91.2 \%$ of the total number. Few research literatures exist in the northwest and Central China. No research literature exists in south China.

The statistics of property and distribution of the first authors' work unit (one time for research object in each literature) are conducted to investigate research direction and contents. The first authors of twenty literatures work in colleges or research centers. The first authors of thirteen literatures are grassroots workers. The first author of one literature works in newspaper office. It shows most authors researching resource rooms for learning in regular class work in colleges or research centers, accounting for $58.8 \%$ of the total number. The grassroots workers rank the second and account for $38.2 \%$ of the total number.

\section{Analysis on the Research Methods}

Among thirty-four literatures related to the research on resource rooms for learning in regular class, six literatures related to quantitative research account for $17.6 \%$; twenty-eight literatures related to qualitative research account for $82.4 \%$; most literatures of qualitative research discuss problems in construction of resource rooms in schools and offer proposals with original thoughts.

Among six literatures of quantitative research, five literatures take single literature as research tool; one literature carries out semi-structured interview for the current situation of construction of resource rooms for learning in regular class.

According to the statistics of frequency that researchers use tools, the six reports of quantitative research involve three research tools, three self-complied research tools and two adapted research tools. The scope of tool contents is narrow. At present, no widely-agreed research tools exist for comprehensive survey of current situation of construction of resource rooms for learning in regular class and investigation on expectations and roles of resource teachers for learning in regular class.

\section{Analysis on Research Contents}

Among the thirty-four literatures related to researches on resource rooms for learning in regular class, eighteen literatures research the practice experience of resource rooms, like Dai Xufang's thinking on development and operation of resource rooms [4], Xu Zhiyan's [5] exploration on regular and special cooperation for course of resource rooms for learning in regular class, and the practical exploration of Yang Guoxing and Wang Guoying to improve the effectiveness of operation of resource rooms [6]; seven literatures research the teachers in resource rooms, like the research of $\mathrm{Yu}$ Kun, Li Zhen and Wang Xiaoyuan on the professional development of resource teachers for learning in regular class [7], the research of Wang Heping on responsibilities of resource teachers for learning in regular class and the evaluation of their job performance [8] and the research of Meng Xiao on resource teachers' roles from supervision, efficiency and teaching strategies [9]. Two literatures relate to guide interpretation like the research of Peng Xiaguang on construction and security system for learning in regular class through interpreting the guide for construction of resource rooms [10]. Five literatures relate to status survey like the investigation of $\mathrm{Li} \mathrm{Na}$ and Zhang Fujuan on current situation of construction and operation of resource rooms for learning in regular class of schools in Shanghai through questionnaires [11] and the investigation of Yang Xijie and Xu Meizhen on the basic situation of preliminary operation of resource rooms for learning in regular class of primary schools of Beijing [12]. Two literatures relate to other researches. Most of the thirty-four research literatures are practical research accounting for $52.9 \%$ of the total number; few guide interpretations exist and account for $5.9 \%$. The practical researches on resource rooms for learning in regular class mainly distribute in construction, operation, course and evaluation of resource rooms. According to the above analysis, at early stage of the research, most researchers pay attention to the status quo of resource rooms for learning in regular class such as the existing problems and analysis of countermeasures. 
As time goes by, researchers research the concrete practice of resource rooms for learning in regular class like construction, operation, course and evaluation. The hotspot is the practice research on resource rooms for learning in regular class.

\section{E. Analysis on Research Hotspots}

According to the above analysis, the summary on practical experience of resource rooms included in eighteen literatures is the research hotspot of resource rooms for learning in regular class. Among the eighteen research literatures, six literatures relate to the construction of resource rooms and summarize the construction mode of regular and special cooperation and the construction of resource rooms by special schools in regular schools; three literatures relate to the operation of resource rooms. Shen Guoxiang and Shao Lifeng discuss the operation of resource rooms from functional presupposition of resource rooms, proposal of individualized plan and practical training [13]. One literature relates to course of resource rooms. Xu Zhiyan divides course of resource rooms for learning in regular class into rehabilitation course and subject compensation course and researches the implementation of courses [14]. One literature relates to the evaluation on functions of resource rooms. Chen Qimin brings the model of method of weighted mean in the evaluation and defines the indicator and concrete contents of evaluation [15]. The above analysis reflects the importance of construction of resource rooms in the development of learning in regular class. The researches are done by grassroots workers and reflect the tendency of combination in research and education.

The research on practice exploration of resource rooms is mature, especially the research on how to construct resource rooms. Researchers pay attention to the evaluation and operation and take the initiative to explore general plans for resource room construction.

\section{ENLIGHTENMENT AND REFLECTION}

According to the history of researches on resource rooms for learning in regular class in the recent twenty years, the number of researches increases day by day, the research tools are increasingly scientific and the research contents alter from current situation of resource rooms to construction, operation and evaluation of it as well as the teachers and the policies. All in all, the researches on resource rooms of our country have benign development tendency. We should also reflect on the existing problems.

\section{A. The Researches on Resource Rooms Gather in the Developed Regions}

The above analysis reveals the researches on resource rooms of our country distribute in North China, Eastern China and the southwest especially in Beijing, Jiangsu and Shanghai. According to the overall economic situation in China, Beijing, Shanghai and Jiangsu locate in developed areas. The imbalance of economic development directly reflects in the investment of educational funds. The construction of resource rooms in some backward areas is difficult and the researches are backward. Some literatures mention small-scale training for resource teachers only exists in developed areas but the training are unsystematic and the flow of resource teachers is large. Relevant data shows [16] the fund ratio of schools in developed areas exceeds $7.95 \%$ and $9.74 \%$ in less developed areas and underdeveloped areas. The fund investment in resource rooms in less developed areas and underdeveloped areas is less, failing to keep the effective operation of resource rooms. The resource rooms in most areas are in name only, leading to few corresponding researches. Therefore, central and western regions should be encouraged to participate in the researches on resource rooms in the future development, in order to improve the national construction level of resource rooms and guarantee the quality of special children in learning in regular class.

\section{B. Most Researches Are Summaries of Practical Experience with Low Research Level}

According to the above-mentioned analysis, most researches focus on summaries of practical experience instead of theoretical researches or researches using scientific and effective tools. The research level is low. There are various reasons. Firstly, the overall development level of learning in regular class of our country is low. People fail to realize the importance of resource rooms. Secondly, the quality of resource teachers is low with large flow, which cannot meet the requirements of teaching in resource rooms. Most resource teachers are backbone teachers of regular school. They also teach regular children and have heavy work task, so that they fail to give consideration to the individualized teaching of special children, let alone doing some researches [17]. Meanwhile, the teachers in resource rooms have low quality and professional development level. They are incompetent in identification and assessment of special children, consultation and communication, individualized teaching, scientific research and administrative affairs. The corresponding training also lacks. [18] Lastly, the research tools for resource rooms are single, including self-compiled or adapted questionnaires, most of which do not go through validity test. For example, in Li Yanling's questionnaire for resource rooms for learning in regular class of Chengdu city [19], although the source and the dimensionality of questionnaires are analyzed, it fails to carry out reliability and validity tests; in the self-complied "questionnaires for the current situation of operation of resource rooms in Shanghai City", Cheng Chen divides the questionnaire into seven factors including resource teaching, evaluation, basic information of resource teachers, management and hardware and basic information of resource rooms. There are 42 questions, but the reliability and the validity are not analyzed. The research tools are backward. As a result, most researches on resource rooms rest on the simple summaries and lack theoretical discussion with low overall research level. In future research, we should develop tools with good reliability and validity, improve theoretical level of the resource teachers and pay attention to the construction of resource rooms to improve the research level.

\section{Resource Courses and Teaching Researches in Relation To Students' Vital Interests Are Inadequate.}

The researches for learning in regular class related to resource courses and teaching are weak. Courses and teaching can guarantee the effective operation of resource rooms and 
play a crucial role in improving the quality of education for learning in regular class. At present, the courses in resource rooms focus on individualized courses supported by activity courses aiming at health intervention, including forms of groups and collectives [20]. However, according to the researches on resource rooms in the recent twenty years, no researches pay attention to the course development. Special children of resource rooms still use the courses in regular school. School-based courses are not developed in accordance to the characteristics of children; no detailed researches exist on how to teach. It only describes phenomenon. Therefore, the educational quality of resource teaching for learning in regular class is low. Course development and teaching research should be strengthened in the future.

\section{CONCLUSION}

During 1996 and 2016, the number of literatures related to researches on resource rooms for learning in regular class increases by years. However, on the whole, the researches are at initial stage. Researchers are staff of colleges or research centers and the research areas focus on developed cities like Beijing and Shanghai to research the construction and operation of resource rooms. Therefore, the researches on resource rooms for learning in regular class can pay more attention to extensive research areas, diversified researchers and pertinent research contents as well as the course and teaching in resource rooms, in order to improve the research quality of resource rooms for learning in regular class.

\section{REFERENCES}

[1] Sun Ying. Construction Status of Resource Room in Beijing and Development Countermeasures $[\mathrm{J}]$, Chinese Journal of Special Education, 2013(1): 20-24

[2] The Ministry of Education of the People's Republic of China, Educational Year-book in 2015 , http://old.moe.gov.cn/publicfiles/business/html files/moe/s8492/list.html.

[3] Yang Xijie, Xu Meizhen. Investigation on Basic Information on Preliminary Operation of Resource Room for Learning in Regular Class in Primary School of Beijing [J], Chinese Journal of Special Education, 2004(6): 7-10

[4] Dai Xufang. Thinking on Development and Operation of Resource Room [J], A Journal of Modern Special Education, 2005(11): 13-15

[5] Xu Zhiyan. Course of Exploration in Resource Room for Learning in Regular Class via Regular and Special Cooperation [J], A Journal of Modern Special Education, 2013(12): 9-10

[6] Yang Guoxing, Wang Guoying. Improve the Effectiveness of Resource Room in Operation [J], A Journal of Modern Special Education, 2011(7):23-25

[7] Yu Kun, Li Zhen, Wang Xiaoyuan. Research on Professional Development of Resource Teachers in Junior High School for Learning in Regular Class [J], 2013(11): 13-15

[8] Wang Heping. Responsibilities and Work Performance Evaluation of Resource Teachers for Learning in Regular Class [J], Chinese Journal of Special Education, 2005(7): 37-40

[9] Meng Xiao. Analysis on Roles of Resource Teachers [J], Chinese Journal of Special Education, 2004(12): 1-4

[10] Peng Xiaguang. Grasp the Quintessence of Construction Guide on Resource Room and Improve the Guarantee System for Learning in Regular Class [J], A Journal of Modern Special Education, 2016(3): 5-7
[11] Li Na, Zhang Fujuan. Investigation on Construction and Operation Status of Resource Room in Schools for Learning in Regular Class in Shanghai [J], Chinese Journal of Special Education, 2008(10): 66-72

[12] Yang Xijie, Xu Meizhen. Investigation on Basic Information on Preliminary Operation of Resource Room for Learning in Regular Class in Primary School of Beijing [J], Chinese Journal of Special Education, 2004(6): 7-11

[13] Shen Guoxiang, Shao Lifeng. Principles and Effective Operation of Remedial Training of Resource Room [J], A Journal of Modern Special Education, 2013(1): 31-33

[14] Xu Zhiyan. Course of Exploration in Resource Room for Learning in Regular Class via Regular and Special Cooperation [J], A Journal of Modern Special Education, 2013(1): 31-33

[15] Chen Qimin. Evaluation the Function of Resource Room [D], Chongqing Normal University, 2007

[16] Wang Zhu, Yang Xijie, Zhang Chong. Investigation on Factors Influencing the Quality of Handicapped Children in Learning in Regular Class [J], Chinese Journal of Special Education, 2006, (5):12

[17] Yang Xijie, Xu Meizhen. Investigation on Basic Information on Preliminary Operation of Resource Room for Learning in Regular Class in Primary School of Beijing [J], Chinese Journal of Special Education, 2004(6): 7-11

[18] Yu Kun, Li Zhen, Wang Xiaoyuan. Research on Professional Development of Resource Teachers in Junior High School for Learning in Regular Class [J], 2013(11): 13-15

[19] Li Yanling. Research on the Construction, Operation Status and Development Countermeasures of Resource Room in Schools of Chengdu City for Learning in Special Class [D], Sichuan Normal University, 2015

[20] Chu Changlou, Wang Chen. Construction and Course Design of Resource Room for Learning in Regular Class [J], A Journal of Modern Special Education, 2014(6):53-54 